2-overexpressing breast cancer: results from the TECHNO trial of the AGO and GBG study groups. J Clin Oncol Off J Am Soc Clin Oncol. 2011;29(25):3351-3357. doi:10.1200/JCO.2010.31.4930

8. Untch M, Rezai M, Loibl S, et al. Neoadjuvant treatment with trastuzumab in HER2-positive breast cancer: results from the GeparQuattro study. J Clin Oncol Off J Am Soc Clin Oncol. 2010;28(12):2024-2031. doi:10.1200/JCO.2009.23.8451

9. Adjuvant Pertuzumab and Trastuzumab in Early HER2-Positive Breast Cancer | NEJM. Accessed June 11, 2021. https://www. nejm.org/doi/full/10.1056/nejmoa1703643

\title{
ĐẶC ĐIỂM LÂM SÀNG VÀ NỒNG ĐộC ĐộC CHẤT HUYẾT THANH CỦA BỂNH NHÂN NGộ ĐộC CẤP HÓA CHẤT DIÊTT CHUộT BROMADIOLON VÀ FLOCOUMAFEN
}

\section{TÓM TẮT}

Mục tiêu: Mô tả đặc điểm lâm sàng và nồng độ độc chất huyết thanh của bệnh nhân ngộ độc hóa chất diệt chuột kháng vitamin $K$ tác dụng kéo dài bromadiolon và flocoumafen tại Trung tâm Chống độc Bệnh viện Bạch Mai. Phương pháp: Nghiên cứu mô tả tiến cứu trên 37 bệnh nhân ngộ độc cấp bromadiolon/flocoumafen điều trị tại Trung tâm chống độc Bệnh viện Bạch Mai từ tháng 6/2020 đến tháng 6/2021. Kết quả: Trong số bệnh nhân nghiên cứu, nam chiếm tỷ lệ $62,2 \%$, hầu hết là người lớn, chỉ có 2 bệnh nhi. Nguyền nhân ngộ độc hay gặp nhất là tự tử, tuy nhiên $27 \%$ không rõ nguồn ngộ độc. Triệu chứng lâm sàng thường gặp nhất xuất huyết dưới da (49\%) và các ổ tụ máu trong cơ (35\%). Một số bệnh nhân xuất huyết nă̆ng như xuất huyết não $(2,7 \%)$, tiêu hoá $(27,03 \%)$, tiết niệu $(27,03 \%)$, ổ bụng $(13,51 \%) .3$ BN $(8,11 \%)$ có sốc mất máu. Nồng đồ Bromadiolon và Flocoumafen xu hướng cao hơn ở nhóm bệnh nhân có xuất huyết hoặc INR > 5 (p 0,06), và cao hơn có ý nghĩa ở nhóm có xuất huyết dưới da nặng ( $p 0,012$ và p 0,027 tương ứng ở Bromadiolon và Flocoumafen). Kết luận: nghiên cứu đã cho thấy các đặc điểm lâm sàng và liên quan giữa biểu hiện xuất huyết với nồng độ độc chất huyết thanh của bệnh nhân ngộ độc cấp hóa chất diêtt chuột bromadiolon và flocoumafen.

Tư khóa: bromadiolon, flocoumafen, ngộ độc cấp, đặc điểm lâm sàng, nồng độ độc chất

\section{SUMMARY}

CLINICAL FEATURES AND SERUM

\section{CONCENTRATION OF BROMADIOLONE}

AND FLOCOUMAFEN POISONINGS

Objectives: to describe the clinical characteristics and serum toxin concentrations of patients with acute

\footnotetext{
${ }^{1}$ Trường Đai hoc Y Hà Nôi,

${ }^{2}$ Trung tâm Chống độc

Chịu trách nhiệm chính: Nguyễn Anh Tuấn

Email: nguyenanhtuanbs1980@gmail.com

Ngày nhận bài: 8.9.2021

Ngày phản biện khoa họ: 29.10.2021

Ngày duyệt bài: 10.11.2021
}

\section{Nguyễn Anh Tuấn ${ }^{1,2}$, Phạm Thị Vân Anh', Đặng Thị Xuân ${ }^{2}$, Hà Trần Hưng ${ }^{1,2}$}

poisoning of long-acting anticoagulant rodenticides bromadiolone and flocoumafen at Vietnam Poison Control Center, Bach Mai Hospital. Methods: A prospective observational study included 37 patients with acute poisoning with bromadiolone/flocoumafen treated at the Poison Control Center from June 2020 to June 2021. Results: Among the study patients, male accounted for $62.2 \%$, most of them were adults, there were only 2 pediatric patients. The most common cause of poisoning is suicide, however, $27 \%$ of poisoning sources were unknown. The most common clinical manifestations were subcutaneous hemorrhage $(49 \%)$ and intramuscular hematomas (35\%). Some patients had severe bleeding such as cerebral hemorrhage $(2.7 \%)$, GI $(27.03 \%)$, urinary $(27.03 \%)$ and abdominal hemorrhage (13.51\%). 3 patients $(8.11 \%)$ had hemorrhagic shock. Bromadiolone and Flocoumafen concentrations tended to be higher in the group of patients with bleeding or INR > 5 ( $p 0.06)$, and significantly higher in the group with major subcutaneous bleeding ( $p$ 0.027 respectively in Bromadiolone and Flocoumafen). Conclusion: The study revealed the clinical features and the relationship between the bleeding manifestations and the serum toxin concentrations of patients with acute poisoning of bromadiolone and flocoumafen.

Keywords: bromadiolone, flocoumafen, acute poisoning, clinical features, serum concentration

\section{I. ĐĂT VẤN ĐỀ}

Các hóa chất diệt chuột (HCDC) ngày càng được sử dụng rộng rãi ở cả nông thôn, thành phố với mục đích bảo vệ nông nghiệp, diệt chuột trong các khu công nghiệp, hộ gia đình... Trong đó $\mathrm{HCDC}$ được xứ dụng phố biến nhất là loại kháng vitamin $\mathrm{K}$ tác dụng kéo dài. Do sẵn có, ngộ độc hóa chất diệt chuột cũng là một trong những cấp cứu thường gặp trên thế giới cũng như ở Việt Nam [1].

Trước đây, ngộ độc HCDC loại kháng vitamin $K$ chủ yếu là wafarin. Tuy nhiên, do sự đề kháng wafarin của chuột, $\mathrm{HCDC}$ phổ biến dần thay thế 
bằng nhóm kháng vitamin $\mathrm{K}$ tác dụng dài, là những hợp chất tan tốt trong lipid, tác dụng rất dài có thể tới nhiều tháng và manh hơn wafarin khoảng 100 lân (do đó còn gọi là superwafarin) [2]. Tại Việt Nam, bromadiolon và flocoumafen là 2 HCDC gây ngộ độc phổ biến nhất. Đặc biệt, bệnh nhân (BN) ngộ độc nhóm HCDC kháng vitamin $\mathrm{K}$ tác dụng dài do độc tính cao, kéo dài thường sẽ gây rối loạn đông máu (RLĐM), chảy máu lâm sàng nặng nề như xuất huyết não, xuất huyết tiêu hóa, chảy máu tiết niệu, chảy máu ổ bụng, dưới da, mắt...có thể tử vong nếu đến muộn hoặc không tuân thủ liệu pháp điều trị vitamin $K_{1}$ dài ngày [3].

Gần đây, Viện khoa học hình sự đã nghiên cứu, triển khai định lượng nồng độ bromadiolon và flocoumafen huyết thanh bằng phương pháp sắc lỏng ký khối phổ (LC-MS/MS). Trung tâm Chống độc (TTCĐ) Bệnh viện Bạch Mai hiện tại đã áp dụng kết quả xét nghiệm định lượng, là bước tiến quan trọng, giúp đánh giá chẩn đoán và theo dõi tái phơi nhiễm, tuy nhiên chưa có nghiên cứu đánh giá. Do đó chúng tôi tiến hành nghiên cứu này với mục tiêu mô tả đặc điểm lâm sàng và nồng độ độc chất huyết thanh của bệnh nhân ngộ độc hóa chất diệt chuột kháng vitamin $\mathrm{K}$ tác dụng kéo dài bromadiolon và flocoumafen tại Trung tâm Chống độc Bệnh viện Bạch Mai.

\section{II. ĐỐI TƯỢNG VÀ PHƯƠNG PHÁP NGHIÊN CỨU}

2.1. Đối tượng nghiên cứu: Các bệnh nhân được chẩn đoán ngộ độc cấp bromadiolon/ flocoumafen nhập viện điều trị tại Trung tâm chống độc bệnh viện Bạch mai từ tháng 6/2020 đến tháng 6/2021.

Tiêu chuẩn chọn bệnh nhân: Bệnh nhân có đủ 2/3 tiêu chuẩn sau:

- Bệnh nhân có uống hoặc ăn phải hóa chất diệt chuột bromadiolon hoăc flocoumafen và xét nghiệm có rối loạn đông máu (INR $>1,5$ ).

- XN độc chất thấy bromadiolon hoặc flocoumafen trong huyết thanh.

\section{Tiêu chuẩn loại trư:}

- Có tiền sử rối loạn đông máu, bệnh gan mật nặng, hoặc đang dùng thuốc chống đông.

- Gia đình hoặc bệnh nhân không đồng ý tham gia nghiên cứu.

2.2. Phương pháp nghiên cứu. Nghiên cứu mô tả tiến cứu

Cách chọn mẫu nghiên cứu: chọn tất cả các đối tượng thỏa mãn tiêu chuẩn chọn trong thời gian nghiên cứu

2.3. Tiến hành nghiên cứu. Các $B N$ đủ tiêu chuẩn sẽ được chọn vào nghiên cứu và đánh giá.
Nhập viện làm bệnh án điều trị và bệnh án nghiên cứu, thu thập các thông tin:

- Các đặc điểm dịch tễ (tuổi/giới, nguyên nhân ngộ độc (tai nạn/tự tử), loại HCDC, thời gian từ khi uống đến vào viện...);

-Biểu hiện lâm sàng: thời gian xuất hiện xuất huyết, đặc điểm xuất huyết dưới da, tụ máu cơ, xuất huyết niêm mạc miệng, chảy máu mũi, XHTH, đái máu, xuất huyết ổ bụng...

-Xét nghiệm prothrombin \%, INR.

- Định lượng nồng độ độc chất Bromadiolon và Flocoumafen tại Viện khoa học hình sự Bộ công an:

+ Máy quang phổ khối bốn cực Waters ACQUITY kết hợp với hệ thống Waters ACQUITY UPLC hoạt động ở chể độ giám sát nhiều lần phân mảnh (MRM). Đầu dò ion hóa electrospray (ESI) được vận hành ở cả hai chế độ ion hóa âm (ES-) và dương $(\mathrm{ES}+)$.

+ Phương pháp: Để thiết lập các điều kiện phân mảnh MRM thích hợp cho các hợp chất riêng lẻ, các dung dịch tiều chuẩn ở mức 100 $\mathrm{ng} / \mathrm{mL}$. Hai kỹ thuật ion hóa khác nhau, ES + và ES-, đã được kiểm tra để đạt được độ nhạy và độ chọn lọc tối ưu [4].

Việc phân tách các chất phân tích được thực hiện trên cột Waters ACQUITY UPLC BEH-C18 (kích thước $100 \times 2.1 \mathrm{~mm}$, kích thước hạt 1.7 ) rửa giải gradient ở tốc độ dòng $0,3 \mathrm{~mL} / \mathrm{phút}$. Pha động là hỗn hợp gồm $10 \mathrm{mM} / \mathrm{L}$ dung dịch amoni axetat $(\mathrm{pH} 7,5)$ (dung dịch rửa giải $\mathrm{A})$ và methanol (dung dịch rửa giải $B$ ).

2.4. Phương pháp xử lý số liệu. Các số liệu được phân tích theo phương pháp thống kê y học, sử dụng phần mềm SPSS 20 . Tính tỉ lệ phần trăm cho các biến định tính, các biến định lượng biểu thị bằng giá trị trung bình, độ lệch chuẩn hoặc trungvị, giá trị nhỏ nhất, lớn nhất, so sánh trung bình bằng $\mathrm{t}$ test, so sánh tỷ lệ \%bằng $X^{2}$ (hoặc Fisher exact test).

\section{KẾT QUẢ NGHIÊN CỨU}

Trong 37 bệnh nhân ngộ độc cấp HCDC đủ tiêu chuẩn tham gia vào nghiên cứu, có 34 bệnh nhân ngộ độc Bromadiolon, 3 bệnh nhân uống Flocoumafen nhưng hàm lượng thấp không rối loạn đông máu (liều uống ghi nhận $0,01-0,05$ $\mathrm{mg} / \mathrm{kg}$ ). BN nam chiếm tỷ lệ $62,2 \%$, hầu hết là người lớn, độ tuổi trung bình trên 50 tuổi, chỉ có 2 bệnh nhi là con bệnh nhân bị ngộ độc ( 4 tuổi và 1 tuổi).

\section{1. Đặc điểm lâm sàng Nguyên nhân ngộ độc}




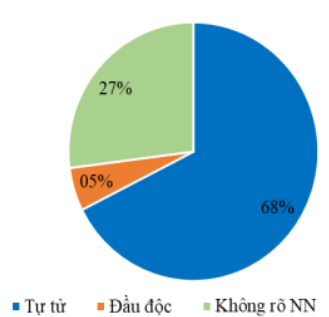

Biều đồ 1. Nguyên nhân ngộ độc

Nhận xét: Nguyên nhân ngộ độc hay gặp nhất là tự tử chiếm hơn 2/3 các trường hợp ngộ độc, tuy nhiên tới $27 \%$ số bệnh nhân khồng rổ nguồn ngộ độc.

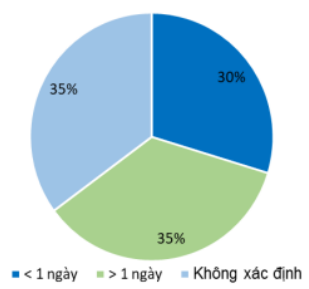

Biểu đồ 2: Thời gian bị ngộ độc đến khi vào viện

Nhận xét: $29,3 \%$ bệnh nhân ngộ độc đến sớm trong ngày đầu thường được rửa dạ dày,

Bảng 1: Mức độ xuất huyết (n=37)

\begin{tabular}{|c|c|c|}
\hline \multicolumn{2}{|c|}{ Các mức độ } & N (Tỷ lệ \%) / Trung vị \\
\hline \multirow{2}{*}{$\begin{array}{c}\text { Mức độ XHDD } \\
(n=18)\end{array}$} & Nhỏ $<1,0 \mathrm{~cm}$ & $4(22,22 \%)$ \\
\cline { 2 - 3 } & Lớn $>1,0 \mathrm{~cm}, 1$ vị trí & $3(16,67 \%)$ \\
\cline { 2 - 3 } & Lớn $>1,0 \mathrm{~cm}$, nhiều vị trí & $11(61,11 \%)$ \\
\hline \multicolumn{2}{|c|}{ BN có sốc mất máu } & $3(8,11 \%)$ \\
\hline \multicolumn{2}{|c|}{ Tống số vị trí xuất huyết } & $3(\min 1 ; \max 8)$ \\
\hline
\end{tabular}

Nhận xét: Có 18 bệnh nhân xuất huyết dưới da, trong đó $77,78 \%$ là xuất huyết dưới da mảng lớn. Có 3 bệnh nhân trong nhóm nghiên cứu có tình trạng sốc mất máu khi vào viện. Hầu hết bệnh nhân có nhiều vị trí chảy máu, trung bình là 3 vị trí

3.2. Nồng độ hóa chất diệt chuột liên quan với lâm sàng

Bảng 2: Nồng độ hóa chẩt diệt chuột với mức độ xuất huyết dưới da

\begin{tabular}{|c|c|c|c|c|}
\hline \multirow{2}{*}{ Mức độ xuất huyết dưới da } & $\mathrm{n}$ & Bromadiolon & \multicolumn{2}{|c|}{ Flocoumafen } \\
\cline { 2 - 5 } & 20 & $380,84 \pm 153,78$ & $\mathrm{n}$ & Nồng độ \\
\hline Không XH hoặc XH nhỏ & 14 & $2264,28 \pm 639,86$ & 10 & $16,03 \pm 7,56$ \\
\hline XH lớn & & 0,012 & & 0,027 \\
\hline p & &
\end{tabular}

Nhận xét: Nồng độ Bromadiolon và Flocoumafen đều có xu hướng cao hơn ở nhóm có xuất huyết dưới da, sự khác biệt trong nghiên cứu của chúng tôi có ý nghĩa thống kê với p 0,012 và p 0,027.

Bảng 3: Nồng độ hóa chât diệt chuột với mức độ rôi loạn đông máu

\begin{tabular}{|c|c|c|c|c|}
\hline \multirow{2}{*}{ Mức độ rối loạn } & \multicolumn{2}{|c|}{ Bromadiolon } & \multicolumn{2}{|c|}{ Flocoumafen } \\
\cline { 2 - 5 } & $\mathrm{n}$ & Nồng độ & $\mathrm{n}$ & Nồng độ \\
\hline Không xuất huyết & 12 & $493,91 \pm 269,42$ & 8 & $46,00 \pm 39,20$ \\
\hline Có xuất huyết và hoặc INR $>5$ & 22 & $1517,71 \pm 453,45$ & 15 & $89,49 \pm 34,24$ \\
\hline p & & 0,061 & & 0,415 \\
\hline
\end{tabular}

Nhận xét: Nhóm bệnh nhân không xuất huyết và INR < 5 có nồng độ Bromadionlon có xu hướng thấp hơn nhóm bệnh nhân có xuất huyết hoặc INR > 5, sự khác biệt ở mức xu hướng, kết quả chưa có ý nghĩa thống kê với p 0.061. 


\section{BÀN LUÂN}

Đặc điểm lâm sàng. Vị trí xuất huyết trong cơ thể có vai trò quan trọng có nguy cơ ảnh hưởng đến sức khoẻ, tính mạng bệnh nhân. Tác giả Barbara E. Watt và CS (2005) [5] tâp hợp các kết quả nghiên cứu của tại các trung tâm chống độc lớn của Mỹ từ 1993 - 2004 thấy rằng thời gian chảy máu nguy cơ tiềm ẩn trong 10 ngày, thời gian gặp nhiều hơn cả chảy máu 1-3 ngày khi nhiễm độc. Nhìn chung tác giả thống kê các vị trí xuất huyết chảy máu da, chảy máu mũi, răng lợi là nhiều nhất. Các cơ quan chảy máu khác cũng hay gặp như cơ khớp, tiêu hoá, chảy máu hô hấp, chảy máu thận tiết niệu sinh dục. Một số bệnh nhân có thể chảy máu nội sọ gẩy hôn mê, chảy máu vùng cổ hầu họng chèn ép hô hấp đe doạ tính mạng. Các bệnh nhân thường bị chảy máu tự nhiên không có tác động của ngoại lực.

Kết quả nghiên cứu của chúng tôi hay gặp nhất là 48,65\% xuất huyết dưới da dang nốt hoặc mảng xuất huyết rộng ở các chi hoặc vùng bụng lưng ngực. Một số ít bệnh nhân có xuất huyết kết mạc, củng mạc. Có $16,22 \%$ đến viện vì chảy máu chân răng khó cầm. $27,03 \%$ chảy máu tiết niệu, tiểu ra máu đai thể, máu đỏ toàn bãi. Vị trí chảy máu nguy hiểm chúng tôi gặp là chảy máu sọ não $2,7 \%$ không có cao huyết áp trước đó. Có 03 bệnh nhân có mất máu nhiều $(8,1 \%)$, rối loạn đông máu nặng, vừa chảy máu tiết niệu và xuất huyết tiêu hoá nặng, lâm sàng thiếu máu nhợt nhạt, vã mồ hôi, tụt huyết áp tư thế phải truyền khối hồng cầu, plasma và vitamin $\mathrm{K} 1$.

Nghiên cứu của Wai Yan $\mathrm{Ng}$, Chor Kwan Ching 2018 [6] trên 42 bệnh nhân hồi cứu trong 03 năm: Tác giả chia ra 2 nhóm $B N$, nhóm có tiền sử phơi nhiễm và nhóm không rõ tiền sử phơi nhiếm, lần lượt tỷ lệ chảy máu lâm sàng là $24,4 \%$ và $100 \%$ (nhóm không biết tiền sử phơi nhiễm thường đến muộn và đều chảy máu). Chảy máu lâm sàng cũng đa dạng, chảy máu bầm tím các chi $7,3 \%$, chảy máu dạ dày $2,4 \%$, chảy máu tiết niệu 4,9\%, chảy máu miệng 9,8\%. Jie Yan and Yangyang Shi (2013)[7] cho thây biểu hiện chảy máu, rối loạn đông máu trên phụ nữa có thai, có nguy cơ sảy thai nghiêm trọng.

Nồng độ Bromadiolon và Flocoumafen đều có xu hướng cao hơn ở nhóm có xuất huyết dưới da, sự khác biệt trong nghiên cứu của chúng tôi có ý nghĩa thống kê với $p 0,012$ và $p 0,027$. Kết quả trên, chúng tôi nhận định rằng phần lớn những bệnh nhân ngộ độc HCDC nồng độ cao sẽ nguy cơ xuất huyết da cơ hơn những bệnh nhân có nồng độ $\mathrm{HCDC}$ mức thấp. Xét nghiệm nồng độ độc chất có giá trị tiên lượng phần nào đó nguy cơ xuất huyết da cơ. Cũng có số ít những bệnh nhân nồng độ HCDC thấp nhưng đến muộn, đã cạn kiệt các yếu tố đông máu dể chảy máu. Đặc biệt những bệnh nhân đến muộn đã trải qua pha thải nhanh của tuần đầu tiên khi nhiễm độc. Một số bệnh nhân nồng độ HCDC cao nhưng điều trị sớm vitamin $\mathrm{K}_{1}$ không có chảy máu.

Khi chúng tôi nghiên cứu chia thành 02 nhóm bệnh nhân không xuất huyết và có INR $<5,0$ có nồng độ Bromadionlon có xu hướng thấp hơn nhóm bệnh nhân có xuất huyết hoặc INR $>5,0$, với $p 0,061$. Nhìn kết quả trên chúng ta thường nhận định, thừa nhận luôn rằng bệnh nhân nặng hơn đương nhiên sẽ̃ có nồng độ HCDC cao hớn. Kết quả p 0,061 cho thây xu hướng khác biêt. Chúng tôi cho rằng có 1 số bệnh nhân đến muộn không xác định chính xác thời gian bị phơi nhiếm do bị đầu độc, do ăn nhầm nhưng không biết, do thời gian dài không nhớ chính xác thời điểm uống. Do thời điểm dịch tễ covid, nên số mẫu nghiên cứu của chúng tôi có phần bị hạn chế để tách riêng được nhóm bệnh nhân này. Dẫu sao kết quả $p$ 0,061 cũng là chỉ số để nhìn thấy được kết quả có xu hướng như trên.

\section{KẾT LUÂN}

Nghiên cứu đã cho thấy các đặc điểm lâm sàng chủ yếu và liên quan giữa biểu hiện xuất huyết với nồng độ độc chất huyết thanh của bệnh nhân ngộ độc cấp hóa chất diệt chuột bromadiolon và flocoumafen.

\section{TÀI LIÊUU THAM KHẢO}

1. Nathan King et all (2015). Long-Acting Anticoagulant Rodenticide (Superwarfarin) Poisoning: A Review of Its Historical Development, Epidemiology, and Clinical Management. Transfusion Medicine Reviews, 8 - 250.

2. G. Richard Bruno (2000). Long-Acting Anticoagulant Overdose: Brodifacoum Kinetics and Optimal Vitamin K. Annals of emergency medicine, 262-267.

3. Yeow-Kuan Chong (2019). Superwarfarin (Long-Acting Anticoagulant Rodenticides) Poisoning, Pathophysiology to Laboratory-Guided Clinical Management, Clin Biochem Rev., 175-185.

4. Sergei Bidny, Kim Gago1 and Mark David (2015). A Validated LC-MS-MS Method for Simultaneous Identifification and Quantitation of Rodenticides in Blood. Journal of Analytical Toxicology, 39(219-224

5. Barbara E. Watt, et al. (2005). Anticoagulant Rodenticides, National Poisons Information Service (Birmingham Centre), City Hospital, Birmingham, UK.

6. Wai Yan $\mathbf{~ N g}$, et al. (2017). Retrospective Study of the Characteristics of Anticoagulant-Type Rodenticide Poisoning in Hong Kong. Journal of Medical Toxicology, Puplished online 23 April 2018.

7. Jie Yan and Yangyang Shi (2013). Vitamin $K$ treatment of brodifacoum poisoning in a pregnant woman. International Journal of Gynecology \& Obstetrics, 122(2), 162-163. 